\title{
MODELLING OF AT ROCKBOLTS PARAMETERS FOR "SOKO" UNDERGROUND COAL MINE
}

\author{
Vladimir Milisavljević, Dražana Tošić, Vojin Čokorilo, Ivica Ristović
}

Original scientific paper Research in this article presents development of numerical model of strata interaction with AT (Advanced Technology) roof support in "Soko" deep coal mine and comparison of modelling parameters with results obtained through experimental measurements. Numerical model is based on finite elements method, using Phase2 software. Comparison showed almost complete concurrence, thus justifying introduction of suggested roadway supporting system into the "Soko" underground coal mine.

Key words: advanced technology; development roadways; rockbolting; roof support; underground coal mines

Modeliranje parametara AT viseće podgrade za rudnik uglja s podzemnom eksploatacijom "Soko"

Izvorni znanstveni članak

U ovom radu je prikazan razvoj numeričkog modela interakcije stijenskog masiva i AT viseće podgrade u rudniku mrkog uglja "Soko", a izvršena je 1 usporedba rezultata dobivenih modeliranjem s rezultatima koji su dobiveni eksperimentalnim putem. Numeričko modeliranje je urađeno metodom konačnih elemenata, uporabom programa Phase2. Usporedba je pokazala da dobiveni rezultati potpuno korespondiraju, što potvrđuje ispravnost uvođenja predloženog sustava podgrađivanja u rudniku "Soko".

Ključne riječi: napredna tehnologija; prostorije otvaranja; rudnik s podzemnom eksploatacijom; sidra; viseća podgrada

\section{Introduction}

Research described in this paper was performed during development of the project "Research on possibility for AT (Advanced Technology) rockbolting application in mines for the purpose of increasing work safety and production efficiency" (TR33025), within Technological Development program (field Energy, mining and energy efficiency). Development of this project is financed by Ministry of Science and Technological Development, Republic of Serbia. Project is developed by University of Belgrade, Faculty of Mining and Geology (RGF) and Technical Faculty (TF) together with Public Company for Underground Coal Mining, Resavica (JPPEU).

Mines at JPPEU have complex opening and developing systems, characterized by large number of active roadways, relatively long for applied mining technology. Most common types of support are steel circular support (36\%), steel arched support (22\%), timber trapezoid support $(11 \%)$ and steel trapezoid support $(6 \%)$. Other types are used less frequently.

In order to overcome existing problems related to development of roadways and maintaining their stability, research was initiated to investigate possibilities for application of new supporting technologies and improvement of general conditions of underground roadways.

Initial investigations indicated that solution could be introduction of active support, i.e. support which reacts before deformation occurs in rocks around the roadway. AT roof support was identified as the most suitable solution. This type of support creates reinforced zone of strata around the roadway, thus reducing propagation of deformation. Beside improved stability of roadway, AT roof support would enable significant improvement regarding reduced requirements for steel support, increased advance rate and reduced need for labour works during roadway development.

\section{Literature review}

Modelling and selection of AT roof bolting parameters is related to the depth of the roadway, strata discontinuities, physical and mechanical properties of rocks around the roadway, intensity and direction of virgin and induced stresses, shape and size of the roadway and similar [1]. Basic parameters which should be determined in process of selection of roof bolting parameters are:

- Diameter and capacity of the bolt;

- Length of the bolt;

- Installation pattern (number of bolts in single row and spacing between successive rows of bolts).

Diameter of the bolts depends on extension strength of the steel, capacity of the bolt and its yielding strength. Diameter of the roof bolt can be calculated according to the following expression:

$D=2 \sqrt{\frac{K_{\mathrm{S}} \cdot R}{\pi \cdot \sigma_{\max }}}$

Where: $K_{\mathrm{S}}$ - coefficient of safety, accepted in range between 2 and 4; $R$ - Loading capacity of the roof bolt; $\sigma_{\max }-$ extension strength of the steel.

Loading capacity for the existing roof bolt can be determined according to previous expression, as follows:

$R=\frac{\pi}{4} \sigma_{\max } \cdot D^{2}$

Other factors could have impact on roof bolt loading capacity beside its diameter and materials. Most important factor is bond strength between the bolt and the rock, i.e. capability of load transfer from the strata-rock to the bolt. 
Lang and Bischof determined relationship between bolt length $\left(L_{\mathrm{S}}\right)$ and width of the roadway $(\mathrm{B})$, which can be used for approximate selection [2]. This relationship can be written as:

$$
L_{\mathrm{S}}=B^{2 / 3}
$$

It was also determined that in case of solid immediate roof of the roadway, required length of the roof bolt is one third of roadway width [3], while in case of weaker immediate roof this length is one half of roadway width [4].

Roof bolt length which is to be installed into the roof in order to act in beam forming mechanism can be determined by the following expression [5]:

$$
L_{\mathrm{S}}=0,12 \cdot I_{\mathrm{R}} \cdot \log _{10}(3,25 H) \cdot\left(\frac{100-C M R R}{100}\right),(\mathrm{m})
$$

Where: $I_{\mathrm{R}}=9,5+(0,2 \cdot C M R R)(\mathrm{m})-$ maximal span in analysed working environment; $C M R R$ - value of coal mines roof rating; $H(\mathrm{~m})$ - depth of the roadway from the terrain surface.

Although the bolt length is one of the basic parameters of roof bolting system, accepted comprehensive model for its calculation is still not published in literature. It can be seen that approach to determination of required length of roof bolt depends on acting mechanism of roof bolting system. In case of suspended load mechanism, required length of the rock bolt is related to width of the roadway, and also length depends on strength of the rock in which the bolt is being installed.

On the other hand, for the case of beam forming mechanism (which is the case for most of the underground coal mines), required length of the roof bolt is determined after natural and mining conditions, which is evaluated by Coal Mine Roof Rating (CMRR) methodology. This approach enables evaluation of mentioned geological information, and it was developed for the purpose of application in underground coal mines for selection of relevant roof bolting parameters [1].

Number of bolts and installation location of each individual bolt in single cross-section (row) represents installation pattern.

Considering interaction between roof support i.e. rock bolts and rock strata it can be concluded that parameters with influence on spacing between successive rows of rock bolts are thickness of immediate roof, location of delamination planes of stratified seams, condition of roof, pre-tensioning of bolts and bolt properties (diameter, length, extension strength) and similar.

Comprehensive approach for determination of roof bolting pattern and spacing between successive rows of bolts was described by Molinda and Mark in [5]. This approach is based on Design Parameter $(P P)$ and it assumes that there is no most important component or parameter for determination of roof bolting pattern and spacing between rows. This parameter includes all of the parameters relevant for roof bolting (length and loading capacity of bolt, number of bolts in single row, spacing between two successive rows of roof bolts), as well as width of the roadway. Design parameter can be calculated as follows:

$$
P P=0,015 \cdot \frac{L_{\mathrm{S}} \cdot N_{\mathrm{S}} \cdot R}{b \cdot B} .
$$

Where: $L_{\mathrm{S}}$ - length of the rock bolt $(\mathrm{m})$, calculated according to expression (4); $N_{\mathrm{S}}$ - number of bolts in a single row; $R$ - loading capacity of the bolt $(\mathrm{kN}) ; b-$ spacing between two successive rows of rock bolts (m); $B-$ width of the underground roadway $(\mathrm{m})$.

On the other hand recommended values of Design Parameter for shallow (to depth of $100 \mathrm{~m}$ ) and deep can be calculated as follows:

- shallow deposits: $P P=15,5-0,23 \cdot C M R R$,

- deep deposits: $P P=17,8-0,23 \cdot C M R R$.

Such approach establishes relation between components of roof bolting system and roadway width on one side and natural, mining and geological conditions, evaluated by Coal Mine Roof Rating (CMRR) index on the other side.

Procedure starts with determination of Design Parameter for specific deposit, according to known roof rating index.

Next step is calculating required length of the roof bolt $\left(L_{\mathrm{S}}\right.$, expression (4)) and bolt loading capacity $(R$, expression (2)). It is assumed that roadway width $(B)$ is already determined in this stage, according to technological requirements. After acceptance of one of the remaining parameters $\left(N_{\mathrm{S}}\right.$ or $\left.b\right)$, second parameter can be calculated. This approach enables selection of several roof bolting patterns and spacing between successive rows. In other words, result of such procedure is several patterns at various spacing, therefore enabling application of other criteria for final selection (economic, technical, technological, etc.).

Described procedure which is based on $C M R R$ index represents comprehensive and contemporary methodology for parameters determination of roof bolting system. This methodology, based on both analytical and empirical approach, can be successfully applied in conditions prevailing in underground coal mines in Serbia.

On the other hand, modelling of stress and deformation in rocks-strata, as well as roof bolts themselves, increases accuracy during evaluation of individual solutions and results of analytical calculations, as described in $[6 \div 8]$.

\section{Modelling of AT roof support with case study}

Research described in this chapter is part of a wider research at the Faculty of Mining and Geology which was related to introduction of AT roof support in Serbian underground coal mines. Previous research included theoretical analysis, numerical modelling, field trials and technology transfer [9], as well as series of experimental field trials in several underground coal mines.

These experimental trials on individual locations included the following activities:

- Core sampling of direct roof, to the depth of $5 \mathrm{~m}$; 
- Drilling trials for selection of drilling consumables and determination of borehole's profile;

- Short encapsulation pull-out tests.

Core sampling of roof strata provides data on type of rocks in which the AT rockbolts will be installed, as well as data necessary for modelling. Beside geological interpretation of coal seam roof, this activity will provide data on physical and mechanical properties of roof rocks, such as uniaxial compressive strength, cohesion and angle of internal friction.

Drilling trials will be performed with various drill bits and drilling rods, in each rock detected in previous activity, in order to identify possible problems which may occur. Part of this activity is determination of borehole profile, drilled with selected drilling consumables. Borehole profile, or variation of borehole diameter along the depth of the borehole, will be used for calculation of required volume of resin for installation of AT rockbolts.

Finally, short encapsulation pull-out test will provide data on load (force) which could be possible to transfer from the rock to the AT rockbolt. This information will be used as a base for modelling in later stages.

The purpose of the research described below is to establish connection between results obtained during analytical stage of AT roof bolting modelling [9] and results obtained during experimental field research [10], [11] and [12].

Main result of the numerical modelling was a conclusion that stability of the underground roadway can be achieved by installing 5 to 6 AT rock bolts into the roof at spacing of maximum $1 \mathrm{~m}$, where length of the rock bolts is $2,4 \mathrm{~m}$. It should be mentioned that number of rock bolts in the junction zone of two roadways is larger. On the other hand, main result of the experimental field trials were results of pull-out tests of short encapsulated AT rock bolt, which is performed in several mines of JPPEU.

Research described in this paper includes modelling of part of the deposit of mine and roadway, which are supported with 5 AT rock bolts of various length. Purpose of the research is to verify loading of the individual bolts.

Brown coal mine "Soko", which is located some 200 $\mathrm{km}$ to the south of Belgrade, was selected for the case study of presented approach. Main problem in this mine is stability of level roadways, which are developed in coal seam by drilling and blasting technology. These roadways have circular cross section with diameter of 3,5 $\mathrm{m}$ and are supported with arched steel rings. Developed model of the "Soko" mine is presented in Fig. 1.

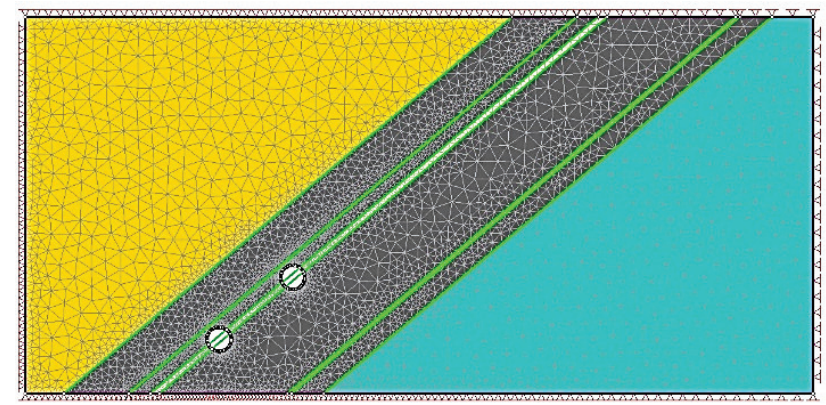

Figure 1 Model of the "Soko" mine
As it can be seen, the model interprets coal seam which is $24 \mathrm{~m}$ thick and inclined at an angle of 40 degrees. Two level roadways are also modelled. These roadways are developed along the intrusion of marlstone. The model also includes two additional intrusions, one of loose marlstone above the roadways and one of clay near the floor of the coal seam. Analysis of stresses and deformation was performed with Phase 2 software.

Rock properties of strata in "Soko" mine which are used for modelling, according to Mohr-Coloumb failure criterion, are given in Tab. 1 [13].

Table 1 Rock properties of strata in "Soko" mine [2]

\begin{tabular}{|l|c|c|c|c|}
\hline \multirow{2}{*}{ Rock type } & $\begin{array}{c}\text { Density } \\
\text { "in situ" } \\
\gamma_{\mathrm{S}}\end{array}$ & $\begin{array}{c}\text { Compressive } \\
\text { strength } \sigma_{\mathrm{c}}\end{array}$ & $\begin{array}{c}\text { Cohesion } \\
\mathrm{C}\end{array}$ & $\begin{array}{c}\text { Angle of } \\
\text { internal } \\
\text { friction } \varphi\end{array}$ \\
\cline { 2 - 5 } & $\mathrm{t} / \mathrm{m}^{3}$ & $\mathrm{MPa}$ & $\mathrm{MPa}$ & 0 \\
\hline Sandstone & 2,65 & 9,36 & 2,40 & 26 \\
\hline Coal & 1,46 & 19,67 & 3,50 & 38 \\
\hline Marlstone & 2,11 & 11,75 & 2,60 & 30 \\
\hline $\begin{array}{l}\text { Clay- } \\
\text { intrusion }\end{array}$ & 1,65 & 15,52 & 2,80 & 33 \\
\hline $\begin{array}{l}\text { Clay and } \\
\text { slate }\end{array}$ & 2,50 & 8,36 & 1,66 & 32 \\
\hline
\end{tabular}

Development of two level roadways incurred principal maximal stress presented in Fig. 2, while total displacement is shown in Fig. 3.

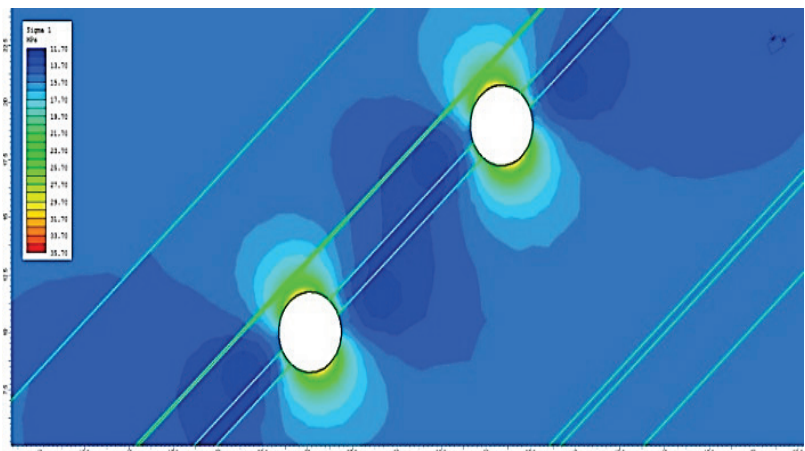

Figure 2 Maximal stress incurred by development of level roadways

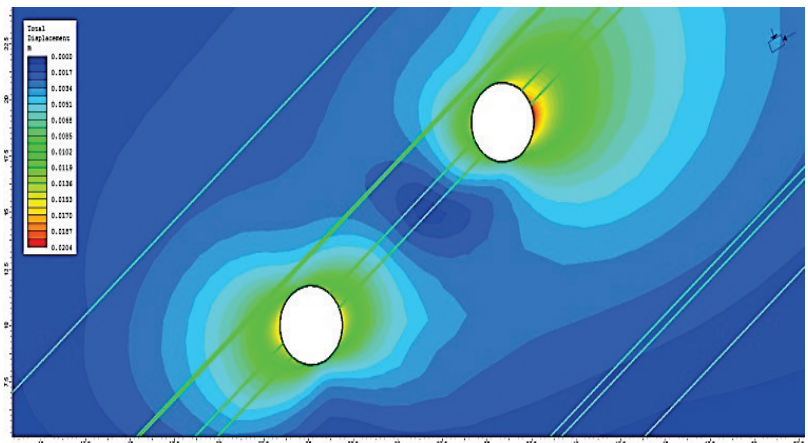

Figure 3 Total displacement incurred by development of level roadways

Next stage of research included simulation of AT rockbolts installation into the roof of roadways. Purpose of this was to determine the load exerted on the rockbolts and to compare these with results obtained during the short encapsulation pull-out test, which are provided in Tab. 2 [11].

As it can be seen, six pull-out tests were performed in "Soko" mine. Bolts 1, 4 and 6 were pulled out from the coal at indicated loads. Average measured bond strength 
is around $105 \mathrm{kN}$, while the result of test 4 , bolt installed at depth of 1,0 $\mathrm{m}$, has lower load since it was installed in crushed coal. Crushed and disturbed rocks around the roadway will have negative impact on load transfer, hence AT roof support should be installed before delaminating and deformation of the rocks [4].

Modelling of installed AT rockbolts of various lengths is shown in Figs. 4, 5 and 6. It can be seen that behaviour of rockbolts is similar. Load transfer is increasing in the areas with higher stress of 20 to $25 \mathrm{MPa}$ (bolts on the left side of the roadways). On the other hand, rockbolts installed in zones with reduced stress (blue areas, on the right side of the roadways) are indicating lower loads.

Table 2 Short encapsulation pull-out test results of "Soko" mine [7]

\begin{tabular}{|c|c|c|c|c|c|}
\hline Test no. & Location & Rock & Depth (m) & Bond strength $(\mathrm{kN})$ & Loading $(\mathrm{kN})$ \\
\hline 1 & EH-(-78)i & Coal-roof & 2,4 & 90 & Failed at 90 \\
\hline 2 & EH-(-78)i & Coal-roof & 2,4 & 110 & Loaded to 200 and held \\
\hline 3 & EH-(-78)i & Coal-roof & 2,4 & 100 & Failed at 100 \\
\hline 4 & EH-(-78)i & Coal-rib & 1,0 & 20 & Failed, fractured coal \\
\hline 5 & EH-(-78)i & Coal-rib & 1,0 & 140 & Loaded to 210 and held \\
\hline 6 & EH-(-78)i & Coal-face & 1,8 & 90 & Failed at 90 \\
\hline
\end{tabular}

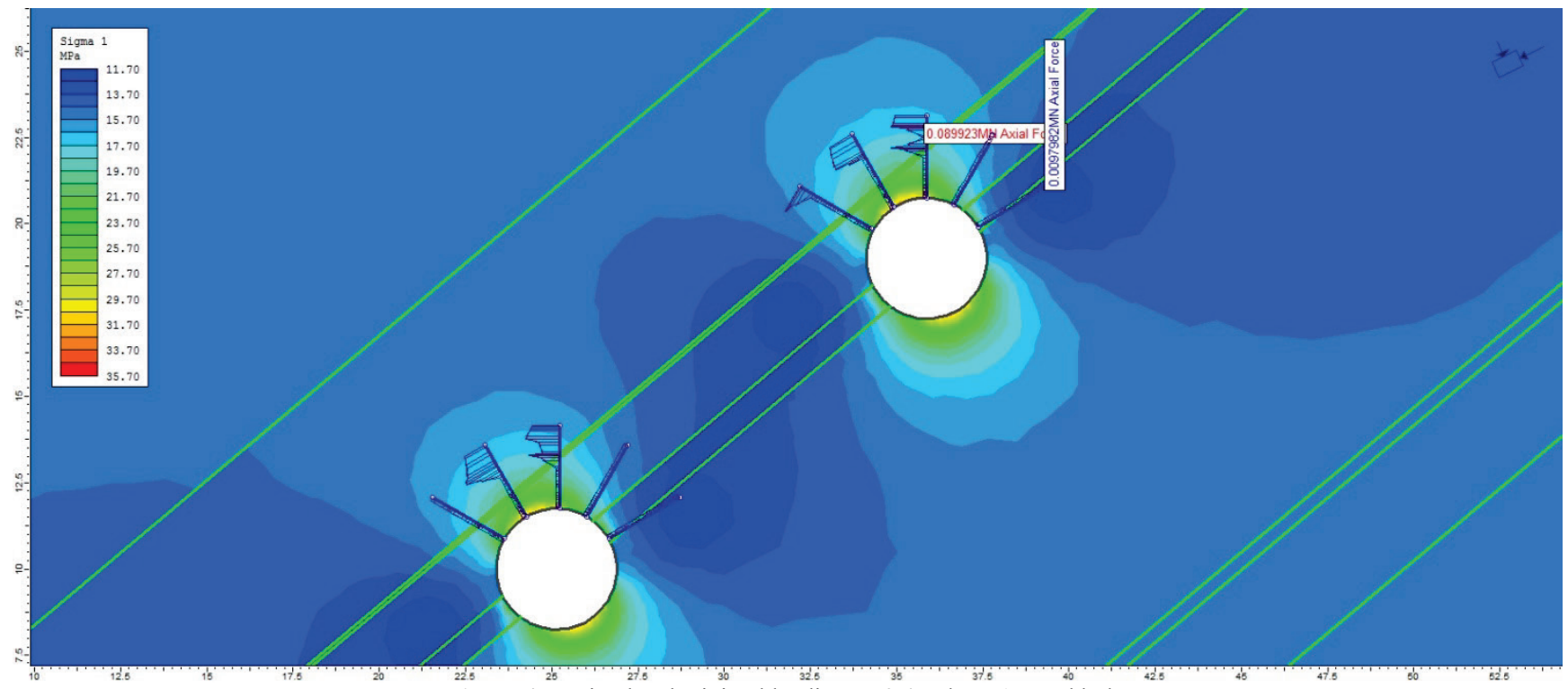

Figure 4 Maximal and minimal loading on $2.4 \mathrm{~m}$ long AT rockbolts

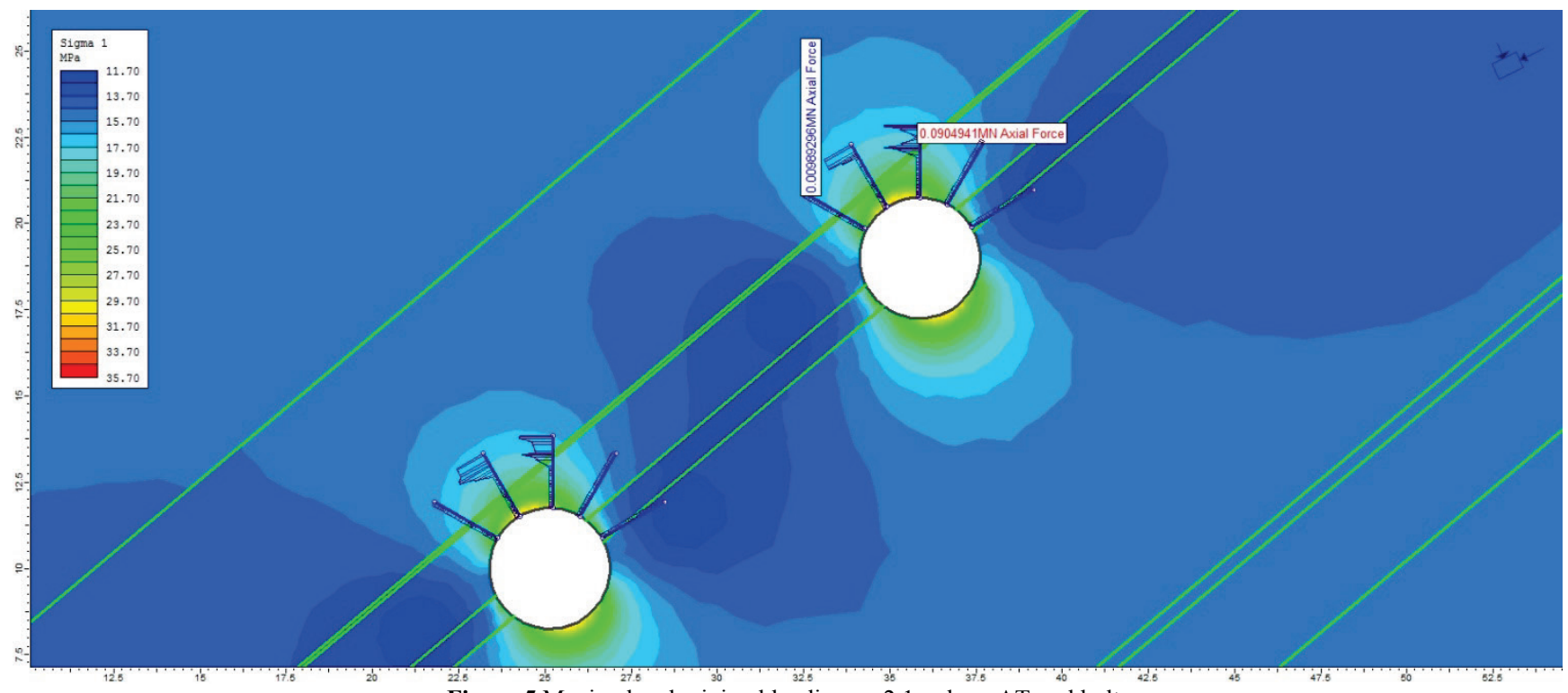

Figure 5 Maximal and minimal loading on 2,1 m long AT rockbolts

It should be mentioned that AT rockbolts means fully bonded rockbolts, made of steel (Elasticity Modulus 200 $\mathrm{GPa}$ ). This model is based on AT rockbolts with diameter of $22 \mathrm{~mm}$.
Axial forces and axial stresses in AT rockbolts $(2,4 \mathrm{~m}$ long, lower level roadway) are shown in Figs. 7 and 8. 


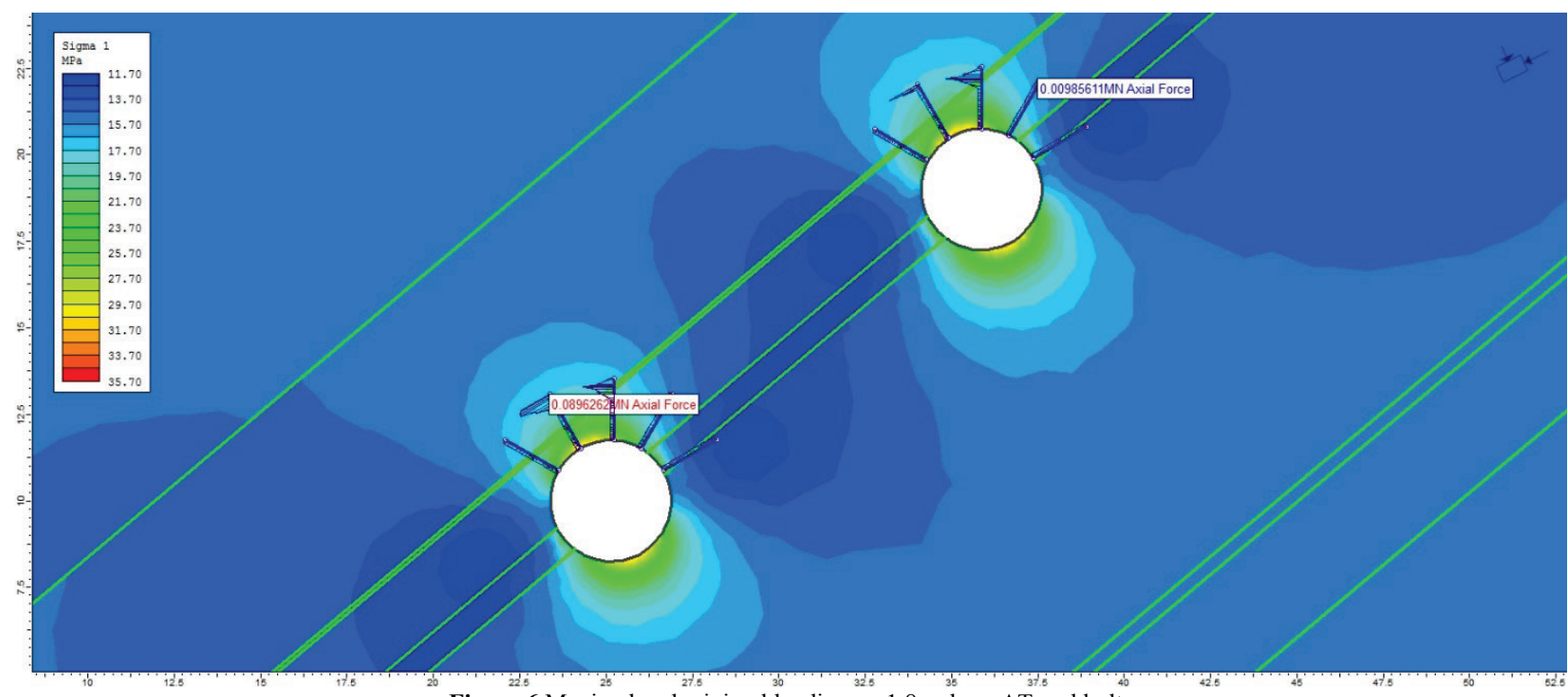

Figure 6 Maximal and minimal loading on 1,8 $\mathrm{m}$ long AT rockbolts

axial force

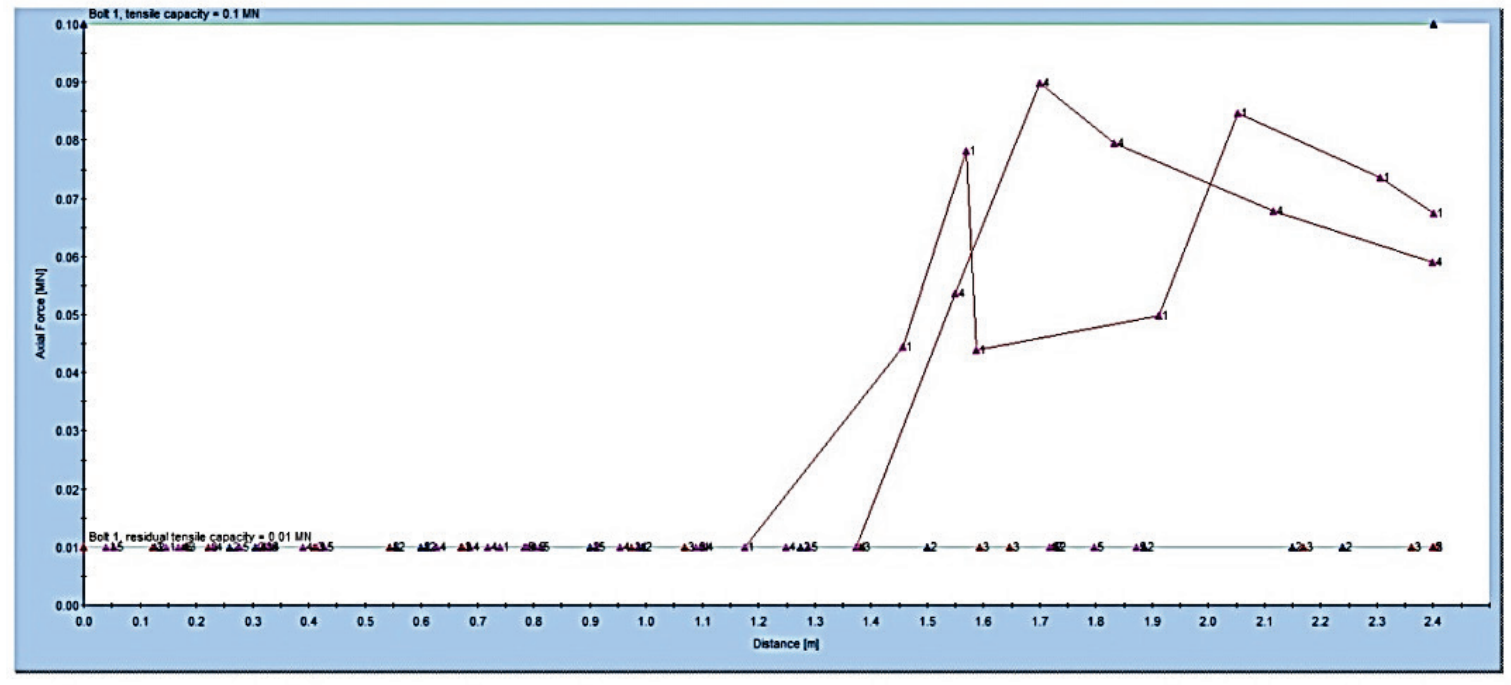

Figure 7 Axial forces in 2,4 m AT rockbolt in lower roadway aved strese

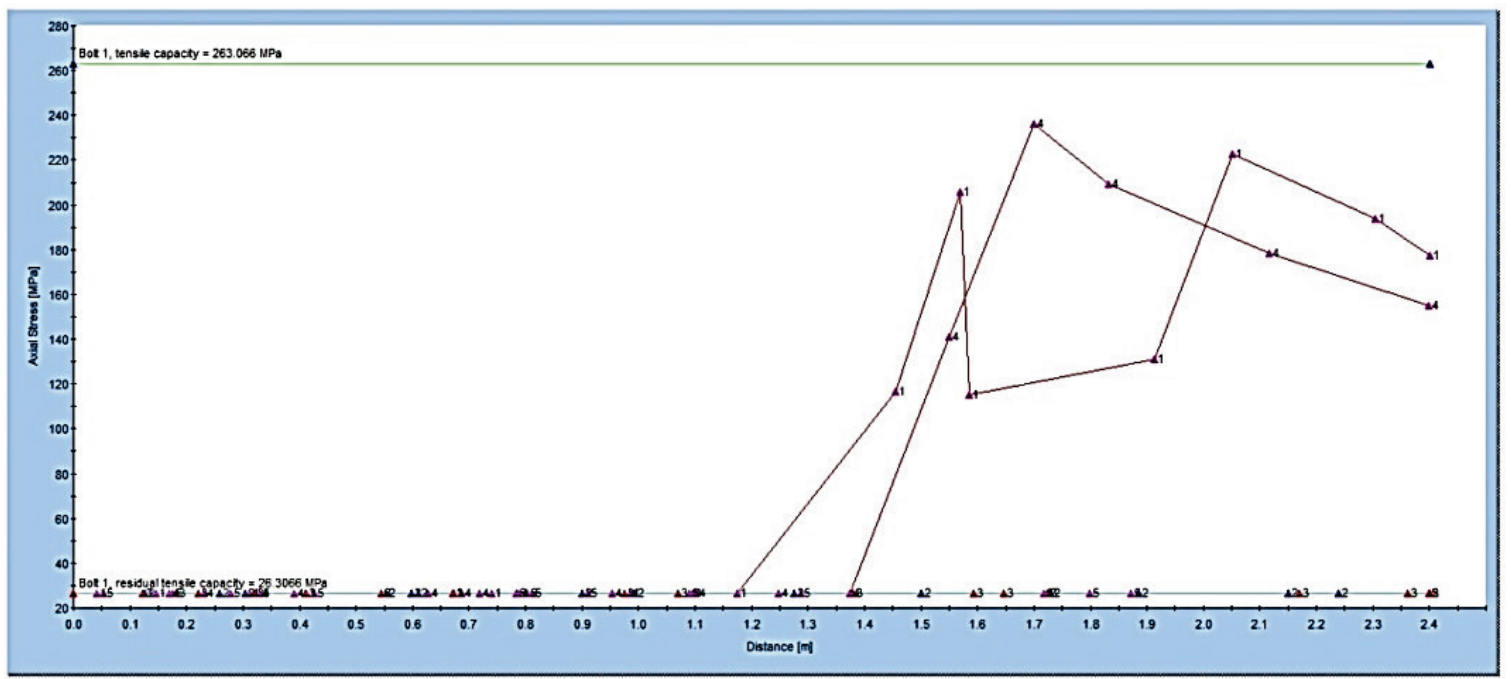

Figure 8 Axial stresses in 2,4 m AT rockbolt in lower roadway

Maximal loads on AT rockbolts for all three cases are given in Tab. 3. Also it should be noted that maximal loads occur in centre bolts for each case, regardless of the length of the bolt. 
Table 3 Maximal loads on bolts

\begin{tabular}{|c|c|}
\hline Bolt length and bolt no. & Load \\
\hline 2,4 m (upper roadway, bolt \#3) & $89,9 \mathrm{kN}$ \\
\hline 2,1 m (upper roadway, bolt \#3) & $90,5 \mathrm{kN}$ \\
\hline $1,8 \mathrm{~m}$ (lower roadway, bolt \#3) & $89,6 \mathrm{kN}$ \\
\hline
\end{tabular}

As it can be seen from figures above, maximal load on the AT rockbolts is approximately $90 \mathrm{kN}$, meaning that rockbolts are not subjected to plastic deformation. Also, it is very important that these values correspond to forces determined with short encapsulated pull-out test (Tab. 2), thus providing additional confirmation and reliability to selected approach of results verification.

\section{Conclusion}

Short encapsulation pull-out tests from coal were performed in "Soko" coal mine (table 2) with average bond strength of $105 \mathrm{kN}$. These results are good, regarding evaluation of load transfer from the rock to the full column resin bonded bolts. Load transfer characteristics are of sufficient strength, thus enabling reinforcement of the surrounding rock mass with AT rockbolts.

Results obtained during experimental part of the research provided base for the next stage of the project development, which includes numerical modelling of AT roof support parameters.

Research presented in this paper confirmed the approach by numerical modelling of AT roof support in almost full concurrence with pull-out tests results. Therefore, it can be concluded that developed model is reliable and can be used for more detailed modelling of AT roof bolting parameters.

\section{Acknowledgment}

Research described in this paper was performed during development of the project "Research on possibility for AT (Advanced Technology) rockbolting application in mines for the purpose of increasing work safety and production efficiency" (TR33025). Development of this project is financed by Ministry of Education, Science and Technological Development of Republic of Serbia.

\section{References}

[1] Molinda, G. M.; Mark, C. Coal Mine Roof Rating (CMRR): A Practical rock mass rating for coal mines, Pittsburgh, PA: U. S. Department of the Interior, Bureau of Mines, IC 9387 (1994);

[2] Lang, T.; Bischoff, J. Stabilization of Rock Excavations Using Rock Reinforcement. // Proceedings $23^{\text {rd }}$ U. S. Symposium on Rock Mechanics, AIME, New York. (1982), pp. 935-944.

[3] Bieniawski, Z. T. Strata control in mineral engineering. New York, NY: John Wiley \& Sons, Inc, (1987).

[4] Jun Lu, L. A New Rock Bolt Design Criterion and Knowledge-Based Expert System For Stratified Roof, Dissertation, Faculty of the Virginia Polytechnic Institute and State University (1999);

[5] Molinda, G. M.; Mark, C. Design of Roof Bolt Systems. In: New Technology for Coal Mine Roof Support. Pittsburgh, PA: U. S. Department of Health and Human Services,
Public Health Service, Centres for Disease Control and Prevention, National Institute for Occupational Safety and Health, DHHS (NIOSH) Publication No. 2000-151, IC 9453 (2000);

[6] Singer, S. P. Field verification of load transfer mechanics of fully grouted roof bolts, Report of Investigation 9301, US Department of the Interior, Bereau of Mines (1990);

[7] Zipf, Jr., R. K. Numerical modelling procedures for practical coal mine design, U.S. Department of Health and Human Services, Public Health Service, Centres for Disease Control and Prevention, National Institute for Occupational Safety and Health (NIOSH) Pittsburgh Research Laboratory, Pittsburgh, PA, USA, CDC 9126;

[8] Jalalifar, H.; Aziz, N. Numerical simulation of fully grouted rock bolts. // In M. Andriychuk (Eds.), Numerical Simulation: From Theory to Industry, University of Wollongong, Faculty of Engineering and Information Sciences. (2012), pp. 607-640. DOI: 10.5772/48287

[9] Milisavljević, V. Izbor elemenata sistema AT viseće podgrade za rudnike uglja sa podzemnom eksploatacijom u Srbiji, Doktorska disertacija, Univerzitet u Beogradu, Rudarsko-geološkifakultet (2010);

[10] Milisavljević, V.; Ristović, I.; Čokorilo, V.; Lilić, N.; Denić, M. Improvement of roadway stability in Serbian underground coal mines. // Proceedings of $4^{\text {th }}$ Balkan Mining Congress, 18-20 October 2011, Ljubljana, Slovenia. (2011), pp. 533-538.

[11] Milisavljević, V.; Ristović, I.; Čokorilo, V. Rockbolting installation trial in Soko underground coal mine. $/ / 12^{\mathrm{th}}$ International Conference "Research and Development in Mechanical Industry" RaDMI 201214 - 17. September 2012, Vrnjačka Banja, Serbia. (2012), pp. 1114-1118.

[12] Milisavljević, V.; Ristović, I.; Čokorilo, V. Installation trial of at rockbolts in Štavalj underground coal mine. $/ / 13^{\text {th }}$ International Conference "Research and Development in Mechanical Industry" RaDMI 201312 - 15. September 2013, Kopaonik, Serbia. (2013), pp. 862-868.

[13] Elaborat o rezervama uglja u rudniku Soko sa stanjem 31.12.2004. godine, JP PEU Resavica, Biro za projektovanje i restrukturiranje rudnika (2004).

\section{Authors' addresses}

Vladimir Milisavljević, Assist. Prof. Dr.

University of Belgrade,

Faculty of Mining and Geology,

Djušina 7, 11000 Belgrade, Serbia

E-mail: vladimir.milisavljevic@rgf.bg.ac.rs

Dražana Tošić, Junior Lecturer, BSc

University of Banja Luka,

Faculty of Mining Prijedor,

Save Kovačevića bb, 79101 Prijedor,

Bosnia and Herzegovina

E-mail: drazana.tosic@unibl.rs

Vojin Čokorilo, Prof. Dr.

University of Belgrade,

Faculty of Mining and Geology,

Djušina 7, 11000 Belgrade, Serbia

E-mail: vojin.cokorilo@rgf.bg.ac.rs

Ivica Ristović, Assoc. Prof. Dr.

University of Belgrade,

Faculty of Mining and Geology,

Djušina 7, 11000 Belgrade, Serbia

E-mail: ivica.ristovic@rgf.bg.ac.rs 